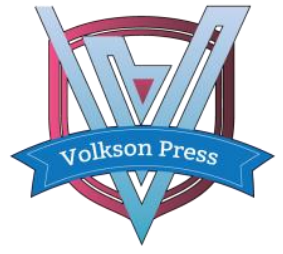

\title{
ANALYSIS OF OVERCAPACITY IN CHINA'S STEEL INDUSTRY
}

\author{
Zhao Haichao \\ Department of North China Electric Power University, No. 2 Huilongguan North Agricultural Road, Changping District, Beijing, China. \\ *Corresponding Author Email: 15910450646@163.com
}

This is an open access article distributed under the Creative Commons Attribution License, which permits unrestricted use, distribution, and reproduction in any medium, provided the original work is properly cited.

\section{ARTICLE DETAILS}

\section{Article History:}

Received 12 March 2018

Accepted 12 April 2018

Available online 15 May 2018

\section{ABSTRACT}

The iron and steel industry is an important basic industry of the national economy, a supporting industry for industrialization, a technology, capital, resource, and energy-intensive industry. It plays a decisive role in the entire national economy. China is the world's largest steel producer and has been trapped in the predicament of overcapacity in steel production in recent years. China's main solutions to overcapacity of steel production are export and reduction of production capacity. The two solutions, on the other hand, are faced with barriers to restricting exports and maintaining social stability. Resolving various difficulties to solve the problem of surplus steel energy is an important task for us to maintain the stability of the steel industry and promote economic growth.

\section{KEYWORDS}

Overcapacity, The Belt and Road, Export volume, Capacity removal, Economy.

\section{ANALYSIS OF THE CURRENT SITUATION OF THE STEEL INDUSTRY}

China is the world's largest steel producer. With the continuous development of China's industrialization, the economic level has been increasing. With the development of household appliances, automobiles, real estate and other projects, the steel industry has also continued to develop, and it has become China's industrialization support and take the heavy responsibility of driving GDP and employment [1]. In the "4 trillion" large-scale stimulus policy of the financial crisis in 2008, steel production capacity increased year by year. However, due to sluggish domestic and foreign market demand, the utilization rate of crude steel capacity has been declining year by year, causing the problem of "overcapacity" in our country.

In 2016, the State Council put forward clear requirements for resolving the excess capacity of the steel industry in the "Thirteenth Five-Year Plan" for the development of the steel industry, reducing steel production capacity by 100 million tons to 150 million tons in 3-5 years, using the "The Belt and Road" initiative and supply. The two-sided structural reforms have facilitated the dual policies. The iron and steel enterprises have actively "gone out" to carry out international capacity cooperation, which is conducive to resolving the excess capacity of the steel industry in China [2].

\section{THE NEGATIVE IMPACT OF EXCESS STEEL CAPACITY}

The overcapacity of steel has brought many negative effects on the Chinese economy.

\subsection{The impact of excess capacity on investment}

Overcapacity will reduce the investment multiplier and weaken the recovery momentum brought by the increase in demand. Overcapacity will weaken the expenditure effect of fiscal policy. At present, the problem of overcapacity has been aggravated and has gradually spread. Whether it is the traditional industry or the emerging industry, or because of the weakening of investment capacity, or because there is a greater risk, companies lack the motivation or ability to invest. Therefore, under the circumstances of the government's expansion of the fiscal policy, the investment multiplier will be reduced, and private investment will be difficult to start.

\subsection{The impact of excess capacity on business operations}

Overcapacity will cause the producer price index to decline and weaken the profitability of the company. Overcapacity means that the market supply exceeds demand, and downward pressure on prices will continue to increase. The general business operation of the company will be difficult, and the loss will increase while the benefit will decline.

\subsection{The impact of excess capacity on monetary policy}

Overcapacity will over-consume funds and affect the normal performance of monetary policies. The effect of monetary policy is that under the circumstances of the government's implementation of the expansion of monetary policy, the main body of the enterprise, especially the private economy, can raise funds at low interest rates to invest, which in turn will drive the macro effect of the increase in aggregate demand [3]. In fact, in China, financial resources are mainly concentrated in state-owned and state-controlled enterprises with excess capacity, and it is difficult for private economy to obtain strong financial support. What we can see in reality is the coexistence of "hot" currency growth and "cold" in the real economy. This is partly due to excessive consumption of new funds by overcapacity industries. Overcapacity industries will dilute liquidity, reduce the monetary policy multiplier, and make it difficult for private enterprises to obtain funds. It is difficult for the monetary policy economic adjustment function to be fully utilized.

\subsection{The financial risk caused by excess capacity}

Overcapacity will result in financial risks, and even lead to wider financial risks in severe cases. Enterprises with overcapacity will face enormous pressure from the buyer's market. Price competition is much more intense than normal market environment. Under such circumstances, the enterprises are generally faced with difficulties in operation and are likely to have financial risks. When they accumulate to a certain degree, they may cause financial risks.

\subsection{The impact of excess capacity on international trade}

Excessive export of surplus steel production capacity will lead to dissatisfaction in other countries and a large amount of compensation measures will be adopted to resist the steel imports from China, which will cause trade friction between countries. 


\section{THE SOLUTION TO OVERCAPACITY}

As for the problem of overcapacity in China's steel industry, the main solution should be to increase exports and reduce production capacity.

\subsection{Export to solve excess capacity}

The "Belt and Road" national strategy provides a vast overseas market for steel production capacity to "go global". In 2017, China's economic growth contributed $30 \%$ to the world economy, affecting the direction of the world economy. Many countries along the "Belt and Road" are in a period of rapid economic development and huge demand for infrastructure. This is the period of large demand for steel products. Through international capacity cooperation, transfer of technology and management experience, and nurturing of local technology and management talents. It promotes local employment and promotes local economic development while at the same time enabling China's excess production capacity to be resolved.

According to the prediction of experts, under the conditions of the IMF's forecast of the GDP growth rate of various countries and China's steel production capacity no longer increasing, the "One Belt and One Road" strategy will annually resolve China's excess steel production capacity. Therefore, in the face of the problem of overcapacity in China's steel industry, it is necessary to build the "Belt and Road".

\subsection{Resolving excess capacity by removing production capacity}

In the face of overcapacity, China cannot rely solely on exports. In 2017, the "three go one drop, one supplement" proposed by General Secretary Xi Jinping's proposed supply-side structural reforms has provided guidelines for reducing production capacity. Although capacity reduction is a work that is difficult to progress, our country has been working hard for it. There are still many problems facing the reduction of excess capacity. The biggest problem is still maintaining social stability.

Since 2016, China has dismantled excess steel production capacity by 1.15 tons and has completely eliminated the production capacity of "Grid Steel". The problem of serious overcapacity in steel production has been basically solved. The utilization rate of steel equipment and steel prices have risen to a reasonable range. Owing to a huge price, 200,000 workers were resettled. Many steel industries in Tangshan, Hebei Province, are currently restricted by the government and must be closed within the specified time. However, many contract workers are directly obliged to buy out their working years. The unemployment of hundreds of thousands of steel industry workers in the country not only imposes a burden on the national economy, but also has an impact on social stability. Cutting down the production capacity also requires the closure of many steel mills. For most mills, rehabilitation is much more difficult than closing, and after resolving excess capacity, if there is a need for large amounts of steel, there is little room for revolving.

\subsection{Improving the quality of steel to solve the energy surplus}

Although China has excess capacity, the steel above the ball-point refills and some air-conditioning washing machines still needs to be imported, and China still needs to import a large amount of steel every year. Therefore, in order to solve the problem of overcapacity in China's steel industry, besides reducing production capacity, it is more important to complete industrial transformation and improve technology as soon as possible. In 2012, China imported 13.66 million tons of steel, which indicates that the supply of high-end steel products is insufficient. However, in recent years, cumulative steel imports have been decreasing each year. "In January-June 2016, the cumulative import of steel products was 6.46 million tons, a year-on-year decrease of $2.9 \%$, and the decrease was narrowed by 0.2 percentage points from January to May 2016, which was 5.3 percentage points lower than the same period of last year." Although China's steelmaking technology is visible, which is constantly improving. The general improvement of steelmaking technology and the reduction of imports means reducing exports, and it is also a solution to overcapacity.

\section{THE IMPACT OF CAPACITY ON CHINA'S ECONOMY-TAKING THE STEEL INDUSTRY OF HEBEI PROVINCE AS AN EXAMPLE}

\subsection{The impact on fiscal taxation and economic growth}

By the end of 2017, Hebei has caused a total of 258 billion yuan in asset losses; affected 55.7 billion yuan in tax revenue (a direct impact on tax revenue of 15.9 billion yuan, indirectly affecting tax revenue of 39.8 billion yuan). In 2013, the impact of measures such as structural adjustment and atmospheric control on industrial added value was about 2 percentage points, and the impact on GDP growth was about 1\%. The GDP growth rate in 2014 was affected by about 1.75 percentage points. In particular, in the first quarter of 2014, the GDP growth rate of Hebei Province was only $4.2 \%$, which was a decrease of about 5 percentage points from the $9.1 \%$ growth rate in the same period last year.

\subsection{The impact on financial credit risk}

The overdue loans of the steel industry in Hebei Province are relatively small, mainly for more than one year. Assuming that the overdue loans mentioned above are all converted to non-performing loans, although the overall impact on the growth rate of the non-performing loan ratio is small, it may have a greater impact on individual banking institutions. Judging from the scale, overdue loans are mainly concentrated in state-owned commercial banks, city commercial banks and other commercial banks. The overdue loans account for $48.77 \%$ and $31.19 \%$ of all overdue loans Judging from the types of institutions, city commercial banks and other commercial banks and cooperative financial institutions have the highest rates of overdue loans, which are $7.85 \%$ and $6.87 \%$, respectively, and may be the two types of institutions that are subject to greater "De-capacity" impact.

\subsection{The impact on employment}

Hebei Province proposed that the "Thirteenth Five-Year Plan" will control the steel production capacity at 200 million tons. According to the national average utilization rate of crude steel of $67 \%$ in 2015 , the crude steel production capacity in Hebei Province is about 280 million tons. From 2017 to 2020, 72 million tons of steelmaking capacity will be phased out, with an average annual elimination of 18 million tons. The number of workers affected each year is approximately 40,000. Taking into account the employment of workers around the steel industry chain service, the actual number of unemployed will be more.

\section{CONCLUSION}

Some people are warning of danger by comparing 2017 to the sword of Damocles in the steel industry. But I'm not going to think it as a sword that doesn't want it to fall. Conversely, it should be slowly, slowly, and even much more slowly, which do not cause excessive fluctuation, either do not leave some troubles.

The biggest obstacle to China's capacity is how to maintain social stability, reduce steel capacity and improve steel quality. I believe, in the General Secretary Xi Jinping as the core of the CPC central committee general secretary, reasonably adjust the structure of the iron and steel industry, people-oriented, earnestly implement the personnel of unemployment of resettlement policy, and the strategy of "area" as a bridge and increase along with the national iron and steel trade, international cooperation between capacity, the steel industry in China will be able to reach the capacity utilization rate of health, and drive to a better quality steady economic development. Note: The sword of Damocles, from ancient Greek legends: King Dionysius invited his friend Damocles to dinner and was ordered to sit under a shimmering sword hanging from a stable The resulting foreign allusion, which means that the commander is in a state of crisis, "extremely declining." Or at any time with a sense of crisis, the heart knocked on the alarm and so on.

\section{REFERENCES}

[1] Wen, Z., Ying, L. 2018. Go out to resolve the iron and steel industry over capacity problem research [J/OL]. Journal of Hebei university of economy and trade, (02), 78-86. https://doi.org/10.14178/i.cnki.issn10072101.2018.02.025.

[2] Reference since China industry information network. 2016. China's steel industry (steel) imports, exports and compared with the same trend analysis", http://www.chyxx.com/industry/201611/464780.html

[3] CMN. 2017. China's production capacity has contributed to the recovery of the world steel market [N]. China metallurgical newspaper, 1128 (001).

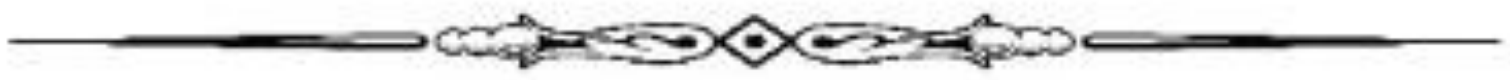

